\title{
Implementasi Blended Learning Selama Masa Pandemi Covid-19 Untuk Menumbuhkan Kemandirin Siswa Pada Mata Pelajaran Matematika Di SD YP Nasional Surabaya
}

\author{
Utami Novita Lestari ${ }^{1}$, Rohana Sufia ${ }^{2}$ \\ 1,2Program Studi PGMI, STAI Al-Fithrah Surabaya, Indonesia
}

\begin{tabular}{|c|c|}
\hline (A) Check for updates open $\partial_{\text {access }}$ (c) & DOI : 10.47400/jiees.v1i2.24 \\
\hline Sections Info & ABSTRACT \\
\hline $\begin{array}{l}\text { Article history: } \\
\text { Received: Oktober } 082020 \\
\text { Accepted: Oktober } 102020 \\
\text { Published online: Desember } 30 \\
2020\end{array}$ & $\begin{array}{l}\text { Blended Learning strategy is considered capable of fostering student } \\
\text { independence and achievement in learning. This learning combines online and } \\
\text { face-to-face learning. The implementation of Blended Learning enables } \\
\text { students to learn effectively and efficiently, more easily access teaching } \\
\text { materials, and in the end increases student learning independence because }\end{array}$ \\
\hline $\begin{array}{l}\text { Keywords: } \\
\text { Blended Learning } \\
\text { Kemandirian }\end{array}$ & $\begin{array}{l}\text { learning is done independently. Learning mathematics is one of the content in } \\
\text { thematic learning in elementary schools. Therefore students must always } \\
\text { participate in learning. As an effort of educational institutions to expand the } \\
\text { reach of learning, implementation, cost efficiency, optimal results, adjusting to } \\
\text { various student needs, and increasing the attractiveness of learning. The } \\
\text { results showed that the implementation of blended learning during the } \\
\text { pandemic in mathematics was very helpful for teachers in delivering material } \\
\text { to students, as well as increasing student independence in learning. }\end{array}$ \\
\hline
\end{tabular}

\section{INTRODUCTION}

Serangan Corona Virus Disease (Covid)-19 membawa dampak yang signifikan pada semua sendi kehidupan manusia. Bidang pendidikan, khususnya pendidikan formal adalah salah satu komponen kehidupan manusia yang terdampak oleh serangan virus tersebut (Herlina, 2020). Proses pembelajaran di sekolah merupakan alat kebijakan publik terbaik sebagai upaya peningkatan pengetahuan dan skill. Selain itu banyak siswa menganggap bahwa sekolah adalah kegiatan yang sangat menyenangkan, mereka bisa berinteraksi satu sama lain. Sekolah dapat meningkatkan keterampilan sosial dan kesadaran kelas sosial siswa. Sekolah secara keseluruhan adalah media interaksi antar siswa dan guru untuk meningkatkan kemampuan intelegensi, skill dan rasa kasih sayang diantara mereka. Tetapi sekarang kegiatan yang bernama sekolah berhenti dengan tiba-tiba karena gangguan Covid-19 (Syah, 2020).

Munculnya wabah Covid-19 yang mendadak dunia pendidikan Indonesia perlu mengikuti alur yang sekiranya dapat menolong kondisi sekolah dalam keadaan darurat (Martoredjo, 2020). Pada masa ini kemandirian belajar merupakan salah satu aspek penting yang harus dimiliki oleh siswa demi tercapainya kompetensi secara optimal, namun nyatanya kemandirian siswa dalam belajar masih kurang baik, mengingat pentingnya sikap ini dan dihadapkan pada situasi yang sulit akibat Covid19 maka pendidik sudah seharusnya melaksanakan pembelajaran yang dapat memfasilitasi terbentuknya kemandirian belajar (Yuliati, 2020). Guru sebagai sumber belajar di sekolah mempunyai tanggung jawab untuk meningkatkan hasil belajar peserta didik menggunakan berbagai metode pembelajaran dan penataan sumbersumber belajar lainnya agar pembelajaran dapat mudah diterima oleh peserta didik 
serta terkesan lebih menarik dan lebih menyenangkan sehingga peserta didik tetap semangat belajar.

Menurut Syah (2020), Terdapat empat kendala yang dihadapi oleh dunia pendidikan di masa pandemi Covid-19 yaitu: 1) Penguasaan internet yang terbatas guru; 2) Kurang memadainya sarana prasarana; 3) Terbatasnya akses internet; 4) Tidak siap dana pada kondisi darurat. Ditinjau dari konten dan mata pelajaran yang diajarkan di sekolah pada masa pandemi, dapat dikategorikan dalam dua kelompok. Kelompok pertama adalah kelompok mata pelajaran yang didominasi oleh teori dan sedikit praktik, sementara kelompok kedua didominasi oleh praktik dengan sedikit teori. Kedua kelompok ini sangat berbeda dalam penerapan pembelajaran online.

Metode pembelajaran semakin berkembang seiring dengan majunya teknologi. Teknologi yang semakin canggih membuat pembelajaran tidak hanya bertatap muka dengan guru dan guru tidak lagi menjadi satu-satunya sumber belajar melainkan dapat melalui media audio, video, audio-video dan komputer yang dikenal sebagai $E$ Learning bahkan dapat menggukan perangkat handphone (Mobile Learning/M-Learning). Hasil penelitian Risalah, dkk. (2020) menunjukkan bahwa pembelajaran online selama masa pandemic memiliki memiliki efek yang bagus terhadap pembelajaran, terutama pembelajaran anak SD/MI, karena anak bisa mengenal dan belajar lewat online dan dapat memanfaatkan teknologi yang ada secara bijak dan lebih mengetahui bagaimana tata cara yang baik dalam menggunakan gadget atau media elektronik yang dapat membantu dalam pembelajaran online yang lainnya.

Selain itu salah satu bentuk pembelajaran yang mampu mengembangkan kemandirian belajar siswa adalah blended learning, pembelajaran ini memadukan pembelajaran secara daring dan juga tatap muka. Bentuk pembelajaran ini memungkinkan siswa dapat belajar secara efektif dan efesien, lebih mudah mengakses materi ajar, dan pada akhirnya meningkatkan kemandirian belajar siswa karena belajar dilakukan secara mandiri (Yuliati, 2020).

\section{RESEARCH METHOD}

Tujuan penelitian ini adalah untuk mengetahui efektifitas blended learning dalam proses belajar selama masa pandemic Covid-19. Metode penelitian menggunakan pendekatan deskriptif kualitatif. Peneliti mengikuti perkembangan proses pembelajaran dengan mendampingi guru dan siswa baik secara luring atau daring. Hal tersebut bertujuan untuk memperoleh deskripsi yang jelas, serta mendukung data hasil wawancara.

Adapun subjek dalam penelitian ini adalah siswa kelas 4 di SD YP Nasional. Siswa kelas 4 merupakan salah satu kelompok siswa dari kelas atas. Mereka memiliki karakteristik yang berada pada tahap operasional konkret yang mana anak tersebut telah mampu berpikir secara logis serta fleksibel, sehingga mereka telah mampu melakukan bentuk aktivitas yang ditentukan dengan aturan yang berlaku.

Metode pengumpulan data menggunakan wawancara, observasi, dan dokumentasi. Ketiganya dilakukan untuk mendukung teori dan telaah pustaka yang telah peniliti kumpulkan. Mengingat kegiatan pembelajaran yang berbasis blended learning ini menuntut siswa untuk menghadiri kelas di sekolah, maka memerlukan 
kerjasama siswa yang mudah diarahkan dalam menerapkan protokol kesehatan yang ketat baik peneliti, dan subyek penelitian.

\section{RESULTS AND DISCUSSION}

Blended learning sebagai kombinasi karakteristik pembelajaran tradisional dan lingkungan pembelajaran elektronik, yakni menggabungkan aspek Blended Learning (format elektronik) dengan pembelajaran tradisional "tatap muka" (Sjukur, 2012).

Komposisi blended yang sering digunakan yaitu 50/50, artinya dari alokasi waktu yang disediakan, 50\% untuk kegiatan pembelajaran tatap muka dan 50\% dilakukan pembelajaran online. Atau ada pula yang menggunakan komposisi 75/25, artinya $75 \%$ pembelajaran tatap muka dan $25 \%$ pembelajaran online. Demikian pula dapat dilakukan $25 / 75$, artinya $25 \%$ pembelajaran tatap muka dan $75 \%$ pembelajaran online (Idris, 2011).

Pertimbangan untuk menentukan komposisinya, bergantung pada analisis kompetensi yang ingin dihasilkan, tujuan mata pelajaran, karakteristik pebelajar, interaksi tatap muka, strategi penyampaian pembelajaran online atau kombinasi, karakteristik, lokasi, karakteristik dan kemampuan pengajar, dan sumber daya yang tersedia (Idris, 2011) Berdasarkan analisis silang terhadap berbagai pertimbangan tersebut, pengajar dapat menentukan komposisi (persentase) pembelajaran yang paling tepat. Hal ini sejalan dengan pendapat Zainudin (2020) bahwa impelementasi ELearning bergantung pada penyelenggara suatu kegiatan, tujuan dan penggunaannya.

Namun demikian, pertimbangan utama dalam merancang komposisi pembelajaran adalah penyediaan sumber belajar yang cocok untuk berbagai karakteristik siswa agar dapat belajar lebih efektif, efisien, dan menarik. Dalam skenario pembelajaran berikutnya tentu saja harus memutuskan untuk tujuan mana yang dilakukan dengan pembelajaran tatap muka, dan bagian mana yang offline dan online (Abdullah, 2018).

Hasil pengamatan selama penelitian menunjukkan bahwa blended learning menggunakan komposisi 50/50 atau semi-daring. Artinya selama proses belajar mengajar 50\% dari total jam pelajaran dilaksanakan dalam bentuk tatap muka konvensional, dan 50\% dalam bentuk online/daring. Tentu saat pelaksanaan tatap muka menggunakan protokol standar Kesehatan yang telah ditetapkan. Sedangkan untuk daring menggunakan sumber belajar Rumah Belajar yang telah disediakan oleh kementerian Pendidikan dan Kebudayaan.

Rumah Belajar memberikan layanan ketersediaan sumber media pembelajaran dalam bentuk bahan belajar interaktif yang dilengkapi dengan media pendukung gambar, animasi, video dan simulasi, serta dalam bentuk buku digital. Konten-konten yang ada pada Rumah Belajar tersebut disediakan untuk berbagai tujuan, agar pendidik dan peserta didik dapat melaksanakan pembelajaran secara komprehensif. Fitur tersebut memfasilitasi pembelajaran daring antara pendidik dan peserta didik kapan saja dan di mana saja. Baik pada saat jam sekolah maupun di luar jam sekolah (sesuai kesepakatan pendidik dan peserta didik), dengan catatan guru dan siswa memiliki koneksi internet dan perangkat gawai seperti komputer/laptop/notebook.

Rumah Belajar dari Kemendikbud yang menyediakan bahan belajar serta fasilitas komunikasi yang mendukung interaksi antar komunitas dalam bentuk laman www.rumahbelajar.kemdikbud.go.id. Rumah Belajar hadir sebagai bentuk inovasi pembelajaran di era industri 4.0 yang dapat dimanfaatkan oleh siswa dan guru dari 
pendidikan dasar hingga pendidikan menengah. Dengan menggunakan Rumah Belajar, maka siswa dapat belajar di mana saja, kapan saja dengan siapa saja. Seluruh konten yang ada di Rumah Belajar dapat diakses dan dimanfaatkan secara gratis. yakni dengan memanfaatkan fitur-fitur yang sesuai dengan materi matematika terutama fitur mengenal sudut. Berikut ini merupakan tebel sajian KD, indikator, dan tujuan pembelajaran pada materi mengenal sudur kelas 4 SD;

Tabel 1. Materi Mengenal Sudut di SD/MI

\begin{tabular}{|c|c|c|c|}
\hline No. & Kompetensi Dasar (KD) & Indikator & Tujuan Pembelajaran \\
\hline 1. & $\begin{array}{l}\text { 3.1.2 Menjelaskan dan } \\
\text { menentukan ukuran } \\
\text { sudut pada bangun datar } \\
\text { dalam satuan baku } \\
\text { dengan menggunakan } \\
\text { busur derajat }\end{array}$ & $\begin{array}{l}\text { 3.12.1 Menganalisis dan } \\
\text { menentukan ukuran sudut } \\
\text { pada bangun datar dalam } \\
\text { satuan baku dengan } \\
\text { menggunakan busur } \\
\text { derajat } \\
\text { 3.12.2 Memahami } \\
\text { pengertian sudut } \\
\text { 3.12.3 Mengidentifikasi cara } \\
\text { membandingkan besar } \\
\text { sudut } \\
\text { 3.12.4 Menganalisis cara } \\
\text { mengukur sudut dengan } \\
\text { busur derajat } \\
\text { 3.12.5 Menganalisis } \\
\text { Menentukan Besar Sudut } \\
\text { Putar }\end{array}$ & $\begin{array}{l}\text { Selama dan setelah } \\
\text { mengikuti proses } \\
\text { pembelajaran } \\
\text { mengamati, menanya, } \\
\text { mengeksplorasi, } \\
\text { menganalisis dan } \\
\text { mengkomunikasikan } \\
\text { peserta didik } \\
\text { diharapkan dapat: } \\
\text { 1. Memahami cara } \\
\text { membandingkan } \\
\text { besar sudut } \\
\text { 2. Memahami cara } \\
\text { mengukur sudut } \\
\text { dengan busur derajat } \\
\text { 3. Mampu X } \\
\text { Menggunakan }\end{array}$ \\
\hline 2. & $\begin{array}{l}\text { 4.1.2 Mengukur sudut } \\
\text { pada bangun datar } \\
\text { dalam satuan baku } \\
\text { dengan menggunakan } \\
\text { busur derajat }\end{array}$ & $\begin{array}{l}\text { 4.12.1 Menggunakan } \\
\text { pengukuran sudut dengan } \\
\text { busur derajat untuk } \\
\text { menyelesaikan masalah } \\
\text { 4.12.2 Menyajikan } \\
\text { penyelesaian masalah yang } \\
\text { berkaitan dengan } \\
\text { pengukuran sudut dengan } \\
\text { busur derajat }\end{array}$ & $\begin{array}{l}\text { pengukuran sudut } \\
\text { dengan busur derajat } \\
\text { untuk menyelsaikan } \\
\text { masalah } \\
\text { 4. Dapat Menyajikan } \\
\text { penyelesaian masalah } \\
\text { yang berkaitan } \\
\text { dengan pengukuran } \\
\text { sudut dengan busur } \\
\text { derajat }\end{array}$ \\
\hline
\end{tabular}

Menurut Husamah (2013), keefektifan Blended Learning masih memiliki celah dalam pelaksanaannya antara lain: 1) Media yang dibutuhkan sangat beragam, sehingga sulit diterapkan apabila sarana dan prasarana tidak mendukung; 2) Tidak meratanya fasilitas yang dimiliki peserta didik, seperti komputer dan akses internet. Padahal, Blended Learning memerlukan akses internet yang memadai dan bila jaringan kurang memadai, itu tentu akan menyulitkan peserta didik dalam mengikuti pembelajaran mandiri via daring; dan 3) Kurangnya pengetahuan sumber daya pembelajaran (pengajar, peserta didik dan orang tua) terhadap penggunaan teknologi. 
Kelemahan tersebut bisa diminimalisir dalam pembelajaran dengan penentuan media yang tepat serta perlunya pembiasaan penerapan.

Berdasarkan hasil wawancara dan observasi terhadap tingkat penguasaan pelajaran matematika khususnya pada materi mengenal sudut, dapat dikatakan bahwa kemampuan siswa di kelas 4 SD YP Nasional Surabaya pada penguasaan materi pelajaran tersebut masih kurang. Selain siswa tidak mampu mengerjakan soal matematika, siswa juga tidak mampu mengidentifikasikan sifat-sifat sudut pada belajar matematika. Sehingga pada saat guru mengadakan ulangan harian yang berhubungan dengan materi pelajaran, kebanyakan siswa di kelas 4 SD YP Nasional Surabaya memperoleh nilai rendah jauh dari harapan ketuntasan belajar matematika yang diharapkan oleh guru dan siswa juga dapat dikatakan kurang memahami konsep pembelajaran.

Dari jumlah siswa sebanyak 24 orang yang tuntas dalam belajar hanya 3 siswa, sedangkan siswa yang tidak tuntas dalam belajar sebanyak 21 siswa. Rata-rata nilai sebelum diberikan tindakan observasi terhadap kelas 4 SD YP Nasional Surabaya adalah 37,70. Sedangkan keberhasilan dalam proses pembelajaran terhadap materi ini yaitu apabila siswa mampu mengerjakan soal matematika dengan jawaban benar dengan nilai 70,00 sesuai dengan KKM yang telah ditentukan di sekolah, serta memperoleh keberhasilan dalam proses belajar mengajar. Berdasarkan pada permasalahan tersebut, maka guru di kelas 4 SD YP Nasional Surabaya berusaha untuk menyelesaikan permasalahan yang dihadapi sehubungan dengan kesulitan siswa memahami mata pelajaran matematika pada materi mengenal sudut. Untuk mengatasi permasalahan tersebut, guru kemudian melakukan perubahan strategi belajar sebagai bentuk upaya peningkatan hasil belajar siswa melalui strategi Blended Learning berbantuan media Rumah Belajar pada mata pelajaran matematika seputar materi mengenal sudut kelas.

Keberhasilan pelaksanaan Blended Learning berbantuan Rumah Belajar ini ditentukan atas hasil belajar siswa dalam menjawab soal matematika. Kriteria keberhasilan atau KKM yang ditentukan oleh sekolah terhadap materi matematika dengan materi pelajaran mengenal sudut yaitu 70,00 dan memperoleh nilai rata-rata dalam kelas 70,00. Sedangkan hasil belajar siswa kelas 4 SD YP Nasional sebelum pelaksanaan strategi Blended Learning berbantuan Rumah Belajar adalah sebagai berikut:

Tabel 2. Hasil Belajar Siswa

\begin{tabular}{llll}
\hline No. & $\begin{array}{l}\text { Rentang } \\
\text { Nilai }\end{array}$ & Jumlah & Kategori \\
\hline 1. & $85-100$ & 0 & $\begin{array}{l}\text { Sangat } \\
\text { Baik }\end{array}$ \\
2. & $70-84$ & 3 & Baik \\
3. & $65-69$ & 5 & Cukup \\
4. & $0-64$ & 16 & Kurang \\
\hline
\end{tabular}

Berikut ini adalah bentuk implementasi dari strategi Blended Learning berbantuan Rumah Belajar dengan memanfaatkan fitur-fitur pada portal Rumah Belajar terkait dengan kegiatan pembelajaran mengenal sudut kelas 4 SD YP Nasional Surabaya. 
Pertama, sebelum kegiatan belajar dimulai guru mengajak semua siswa berdoa sesuai dengan agama masing-masing, presensi siswa, memulai pelajaran dengan apersepsi serta memberikan motivasi belajar. Pada kegiatan ini siswa diminta memperhatikan dan memahami materi pecahan, sifat-sifatnya dan siswa mampu meng-upload materi pada portal Rumah Belajar tersebut. Guru melibatkan siswa untuk mencari dan menemukan informasi yang luas sehubungan tentang topik atau tema materi yang akan dipelajari. Selanjutnya memfasilitasi terjadinya interaksi antara siswa dengan guru, lingkungan dan sumber belajar lainnya dengan kegiatan:

1. Pendahuluan ( \pm 15 menit)

Guru memulai pembelajaran dengan memberikan salam dan menanyakan kabar. Kemudian mengajak siswa berdo'a bersama dan menyanyikan lagu Indonesia Raya dilanjutkan dengan memberikan motivasi kepada siswa dengan mengajak untuk melakukan tepuk semangat, kemudian mengecek kehadiran siswa serta memastikan situasi kelas dalam keadaan kondusif. Kemudian dilanjutkan dengan fase pertama dari pembelajaran Blended Learning berbasis Rumah Belajar yaitu mengenalkan Rumah Belajar melalui smartphone, guru memberikan apersepsi dengan memberikan pertanyaan kepada siswa.

2. Kegiatan Inti ( \pm 75 menit)

Pada kegiatan inti, guru melaksanakan fase pembelajaran dalam model blended learning berbasis rumah belajar dengan tahapan: 1) Merumuskan topik yang dibahas; 2) Membuat hipotesis atau jawaban sementara; 3) Mengumpulkan dan menganalisis data; 3) Menyajikan hasil belajar, dan; 4) merumuskan kesimpulan untuk dicatat siswa.

3. Kegiatan Penutup ( \pm 15 menit)

Pada kegiatan penutup, guru melakukan refleksi terhadap pembelajaran dan materi yang telah dilakukan. Guru bersama siswa membuat kesimpulan terhadap materi mengenal sudut. Guru memberi kesempatan kepada siswa untuk bertanya tentang hal yang kurang atau tidak dimengerti. Kegiatan dilanjutkan dengan mengerjakan tes akhir pembelajaran (post-test) secara individu dengan tertib. Guru menutup pembelajaran dengan berdoa dan mengucapkan salam.

Hasil belajar yang diperoleh pada pelaksanaan strategi blended learning berbantuan website rumah belajar pada pertemuan ke-5 dalam kegiatan pembelajaran ini merupakan indikator keberhasilan. Untuk jelasnya dapat dilihat dari nilai hasil belajar siswa yang tercantum dalam tabel berikut ini:

Tabel 3. Hasil Belajar Siswa

\begin{tabular}{llll}
\hline No. & $\begin{array}{l}\text { Rentang } \\
\text { Nilai }\end{array}$ & Jumlah & Kategori \\
\hline 1. & $85-100$ & 10 & $\begin{array}{l}\text { Sangat } \\
\text { Baik }\end{array}$ \\
2. & $70-84$ & 12 & Baik \\
3. & $65-69$ & 1 & Cukup \\
4. & $0-64$ & 1 & Kurang \\
\hline
\end{tabular}

Kemudian ketuntasan dari hasil belajar siswa tercantum dalam tabel berikut ini: 
Tabel 4. Ketuntasan Hasil Belajar Siswa

\begin{tabular}{llll}
\hline No. & $\begin{array}{l}\text { Rentang } \\
\text { Nilai }\end{array}$ & Jumlah & Kategori \\
\hline 1. & $70-100$ & 22 & Tuntas \\
2. & $0-69$ & 2 & $\begin{array}{l}\text { Tidak } \\
\text { Tuntas }\end{array}$ \\
\hline
\end{tabular}

Berdasarkan hasil pelaksanaan strategi Blended Learning tersebut, dapat disimpulkan bahwa siswa kelas 4 SD YP Nasional Surabaya telah mengalami peningkatan terhadap hasil belajar mata pelajaran matematika pada materi mengenal sudut. Terdapat 22 siswa yang tuntas dan 2 siswa yang tidak tuntas, pada siswa yang tuntas maka telah berhasil mendapatkan nilai sesuai dengan KKM yang telah ditentukan oleh sekolah. Peningkatan hasil belajar tersebut terjadi pada aspek pengetahuan dan keaktifan siswa dalam pembelajaran.

\section{CONCLUSIONS}

Dapat disimpulkan dari hasil pelaksanaan strategi blended learning berbantuan website Rumah Belajar sebagai bentuk upaya peningkatan hasil belajar siswa mata pelajaran matematika pada materi mengenal sudut bahwa siswa kelas 4 SD YP Nasional Surabaya telah mengalami peningkatan. Manfaat yang diperoleh melalui pelaksanaan strategi blended learning berbantuan Rumah Belajar, antara lain:

1. Bagi Siswa:

a. Meningkatkan hasil dan proses pembelajaran siswa terutama pembelajaran matematika.

b. Memberikan motivasi pada minat belajar siswa pada pembelajaran matematika kelas 4 SD YP Nasional Surabaya dengan media rumah belajar.

c. Memberikan kemampuan bagi siswa untuk mengerjakan soal-soal matematika terutama pada materi pelajaran mengenal sudut.

2. Bagi Guru:

a. Mampu meningkatkan kemampuan mengajar guru, dengan menggunakan media mengenal sudut sehingga hasil belajar matematika siswa kelas 4 SD YP Nasional Surabaya meningkat dalam menyelesaikan soal matematika.

b. Mampu melakukan penilaian tehadap proses belajar siswa khususnya pelajaran matematika.

3. Bagi Sekolah:

a. Sebagai bahan evaluasi dalam kegiatan pembelajaran matematika di kelas 4 SD YP Nasional Surabaya.

b. Mengetahui efektifitas pengunaan media rumah belajar pada materi pelajaran matematika.

c. Sebagai bahan masukan bagi guru di sekolah.

\section{ACKNOWLEDGEMENTS}

Penulis mengucapkan terima kasih kepada Program Studi PGMI, STAI AlFithrah Surabaya atas dukungan dan bantuan dalam menyelesaikan penelitian ini. 


\section{REFERENCES}

Abdullah, Walib. (2018). Model Blended Learning dalam Meningkatkan efektivitas Pembelajaran. Jurnal Pendidikan dan Manajemen Islam, 7(1), 7.

Belajar, Rumah. Belajar di Mana Saja, Kapan Saja, dengan Siapa Saja, (https://belajar.kemdikbud.go.id/Dashboard/Home/About), diakses pada 6 Agustus 2020.

Herlina. (2020). Potensi Pembelajaran Pendidikan Jasmani Olahraga dan Kesehatan (PJOK) di Tengah Pandemi Corona Virus Disease (Covid)-19 di Sekolah Dasar. Tadulako Journal Sport Sciences And Physical Education, 8(1), 2.

Husamah. (2013). Pembelajaran Bauran (Blended Learning). Jakarta: Hasil Pustaka.

Idris, Husni. (2011). Pembelajaran Model Blended Learning. Jurnal Iqra', 5(1), 6.

Martoredjo, Nikodemus Thomas. Pandemi Covid-19: Ancaman atau Tentangan bagi Sektor Pendidikan?, (https://core.ac.uk/download/pdf/328807842.pdf) diakses pada 9 November 2020.

Risalah, Ainur, Ibad, W, Maghfiroh, L, Azza, M I, Cahyani, S A, \& Ulfayati, Z A. (2020). Dampak Pandemi Covid-19 Terhadap Kegiatan Belajar Mengajar Di MI/SD (Studi KBM Berbasis Daring Bagi Guru dan Siswa). Journal of Islamic Education Elementary School, 1(1). https://doi.org/10.47400/jiees.v1i1.5

Sjukur, S.B. (2012). Pengaruh Blended Learning terhadap Motivasi Belajar dan Hasil Belajar Siswa Tingkat SMK. Jurnal Pendidikan Vokasi, 3(2), 368-378.

Syah, Aji Rizqon Halal. (2020). Dampak Covid-19 pada Pendidikan di Indonesia: Sekolah, Keterampilan, dan Proses Pembelajaran. Jurnal Sosial \& Budaya Syar-i, 7(5), 396.

Taseman, Iman Rasiman, Arumi Puji Lestari, Atik Anturichana, Hanyfa Maulidiyah, H. H. (2020). IMPLEMENTASI EVALUASI SOAL PEMBELAJARAN IPS THE IMPLEMENTATION OF LEARNING EVALUATION ON SOCIAL STUDIES BASED ON 2013 CURRICULUM AT MI ASSYAFI' IYAH. AULADUNA: Jurnal Pendidikan Dasar Islam, 7(1), 74-80

Yuliati. (2020). Membangun Kemandirian Belajar Mahasiswa Melalui Blended Learning di Masa Pandemi Covid-19. Jurnal Elementaria Edukasia, 3(1), 1.

Zainudin, Agus. (2020). E-Learning Berbasis Moodle Sebagai Media Informasi, Teknologi DanKomunikasi Guna Mencegah Penyebaran COVID-19. Journal of Islamic Education Elementary School, 1(1). https:// doi.org/10.47400/jiees.v1i1.6

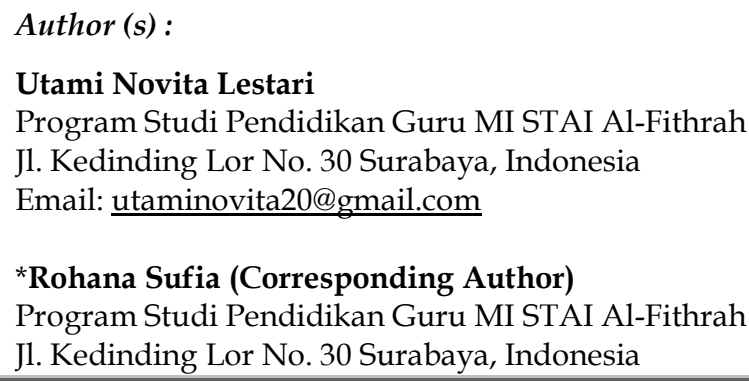


JIEES : Journal of Islamic Education at Elementary School Homepage : http://jiees.alkhoziny.ac.id/index.php/jiees Email : jiees@alkhoziny.ac.id
p-ISSN : 2723 -7184; e-ISSN : 2723-8148

JIEES, Vol. 1, No.2, Desember 2020 : 103-110

(C) 2020 JIEES :

Email: rohana.sufia90@alfithrah.ac.id 